\section{The Plaut Report}

In the twilight hours of the former Liberal government of Canada, the Minister of Employment and Immigration, the Honourable John Roberts, appointed Rabbi Gunther Plaut "to find a means of providing a scrupulously fair system for determination of refugee claims in Canada that is also expeditious and viable given the financial and human resource constraints that apply in the public sector."

The terms of reference required the rabbi to assess the existing problems and causes of the backlog of refugee claimants in Canada, formulate alternatives for dealing with refugee determination either within or independent of Immigration program administration, and, after widespread consultation and investigation and considerations of law and juroptions for a Canadian system which "would respond to human rights commitments, Canada's international obligation control function."

On April 17, 1985, the 221-page Plaut Canada,"including its nine appendices, was officially submitted to the Honourable Flora Macdonald, Minister of Canada's Employment and Immigration Commission (CEIC). In a press release by the Minister on July 17 dealing with the Plaut Report, Canadians were promised the Report would form the basis of a isprudence, to provide at least two tions and the interface with the immigraReport on "Refugee Determination in major, comprehensive overhaul of legislation affecting refugee determination by the fall. While we await the reform package, extracts from and several analyses of the Plaut Report follow.

\section{Independence}

The report correctly places the refugee determination process in the context of the tension between the responsibilities of immigration authorities to control entry into Canada given current conceptions of sovereignty, and the fact "that Canada, by adhering to the (Refugee) Convention and having made its principles part of Canadian law, has voluntarily limited its sovereignty in this one respect." Non-citizens claiming refugee status have rights to claim to be allowed to stay in Canada.

To resolve this tension and ensure the separation of concerns, the determination whether or not a person is a refugee must be made by an independent body. (p. 20)

A central issue is whether Plaut's recommendations adequately protect that independence. Though the determinathe hands of a separate Refugee Board, the Plaut Report recommends the appointment of Refugee Officers (ROs) within CEIC

While many submissions have urged me to separate the CEIC completely from the refugee determination protion of refugee status has been placed in

\section{RABBI GUNTHER PLAUT}

"I was a refugee once, having fled from Hitler under whose rule I had lived for more than two years. I came to the New World exactly 50 years ago, after finishing law school in Germany and having been deprived of pursuing my chosen profession because I was a Jew. In a miniscule fashion my own life rehearses the story of my people who have been refugees all too often. I know the heart of the refugee, a person who desperately seeks for a place to stand, for the opportunity to be accepted as an equal amongst fellow humans.

"I belong to the fortunate ones whose quest has been generously answered. My personal experience and my own religious tradition have moved me to put on Canada's national agenda the larger issues that arise from a consideration of refugees and their problems."

(The above statement by Rabbi Plaut is taken from the introduction to Part II of his Report on Refugee Determination, not yet published by the Minister.) cess, I deem it essential that a proper liaison between the CEIC and the RB be maintained. The liaison is to be effected by a new category of CEIC personnel, the Refugee Officer (RO).

The ROs are to be jointly selected by the $\mathrm{RB}$ and the CEIC, trained by the RB and seconded to the RB for a minimum threeyear term, just as many refugee policy directors have in the past been seconded from External Affairs. The ROs will function within CEIC to provide counselling and support to refugee claimants. A CEIC officer should have the right to present evidence at a hearing when deemed appropriate, but in an information-sharing capacity and not in an adversarial way.

Amnesty International's brief to the Minister seems to endorse this limited information-sharing, non-adversarial role of the CEIC with the qualification that "the person concerned should be allowed ample notice of such evidence, and given an opportunity to respond thereto."

\section{Fairness}

Everyone agrees the system must be fair. Most endorse the Plaut recommendation that in order to be fair, it must be nonadversarial. Further it is generally agreed that the training and abilities of the initial hearing officers at the first stage are the most crucial factors in determining fairness. The Plaut Report's recommendations to set up both an educational and a documentation division, as well as ensuring a quality selection and training procedure for both ROs and members of the $\mathrm{RB}$, constitute some of the most important recommendations in the report.

Since the Supreme Court has already required oral hearings to ensure fairness, one crucial issue is the quality of that body. Amnesty International endorses the model which provides for a threeperson panel at the initial hearing and decision stage rather than a one person panel (see article by Michael Schelew, former President of Amnesty International (Anglophone), Canada, in this issue).

The other crucial issue regarding fairness is access to the system itself. One of the most important contributions of the Plaut Report is the decimation of the concept of 


\section{Plaut Report (cont'd from p. 3)}

a manifestly unfounded claim, and the procedure by which claims are determined to be manifestly unfounded in order to limit access to the system by such claimants. As Plaut argues, a claim by its very character must be rationally considered and weighed before its value can be assessed; by its very nature, the value of a claim cannot be manifest or apparent. Further, the vast majority of claims, even when rejected, are not unfounded; they are inadequately supported to meet the strict criteria of the Refugee Convention. Such claims are not abuses of the system. Hence, Plaut rejects pre-screening. Plaut does introduce a category of inadmissible claims to be determined by the RB, such as the claimant: not basing the case on fear of persecution; not filing before the expiration of a time limit (say six months) after arrival in Canada; or filing a repeat claim. The panel representing the Concerned Delegation of Church, Legal and Humanitarian Organizations argued that a time limit might interfere with the principle of fairness.

\section{Expeditious}

Balancing the principle of fairness was the requirement that the procedure be expeditious. In fact, as many have pointed out, an expeditious procedure is necessary to guarantee fairness. Plaut offered three models (see boxes). The first provides for an initial three-member panel but allows for no review within the system. Model B has only a one-member initial hearing and a central threemember review panel without an oral hearing. Model $\mathrm{C}$ allows for an oral hearing de novo.

In the briefs to the Minister, the delegates asked for the ideal elements of all the models - an initial three-member panel and an appeal procedure which allows for de novo hearings. No cost estimates were presented by the delegates. Nor were comparisons made with applications of the principle of fairness to administrative hearings in other contexts such as compensation for victims of crime or work injuries. The delegates reiterated over and over that in cases where the life of the refugee claimant may be at stake, it is crucial to take every precaution to ensure fairness.

The Plaut Report included the requisite recommendations on procedural guarantees, including notice requirements, fair
Model A

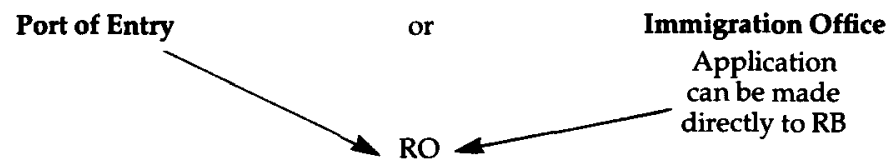

Interview to obtain basic data and give advice and referral where applicable<smiles>[R17]1CCC1</smiles>
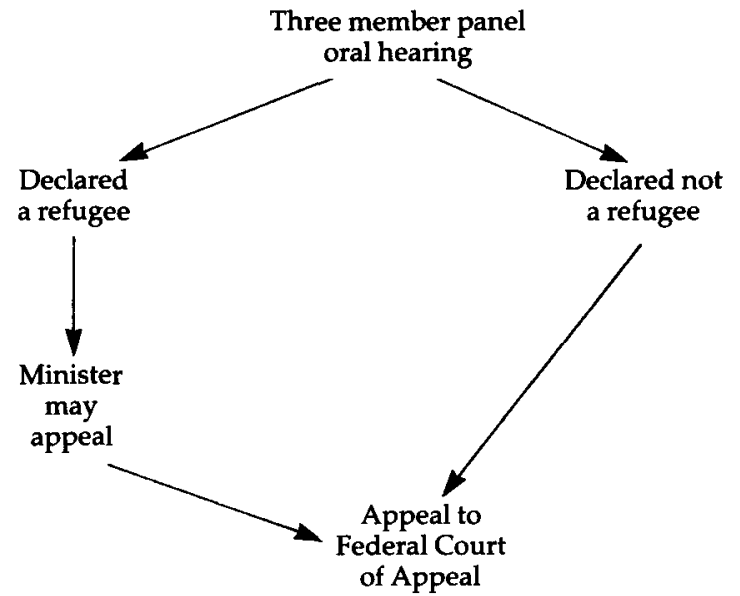

Model B

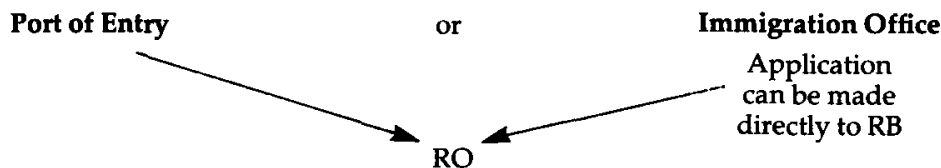

Interview to obtain basic data and give advice and referral where applicable
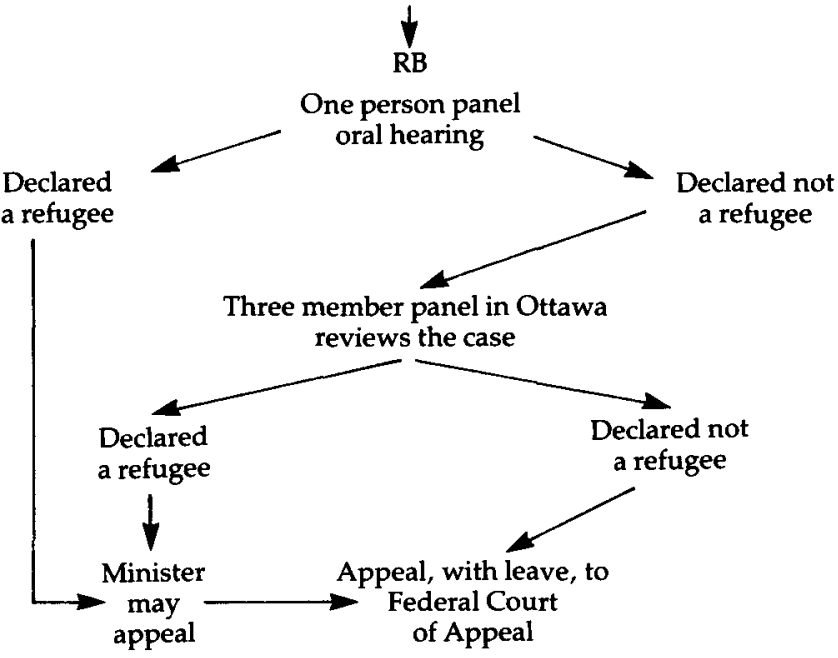
Model C

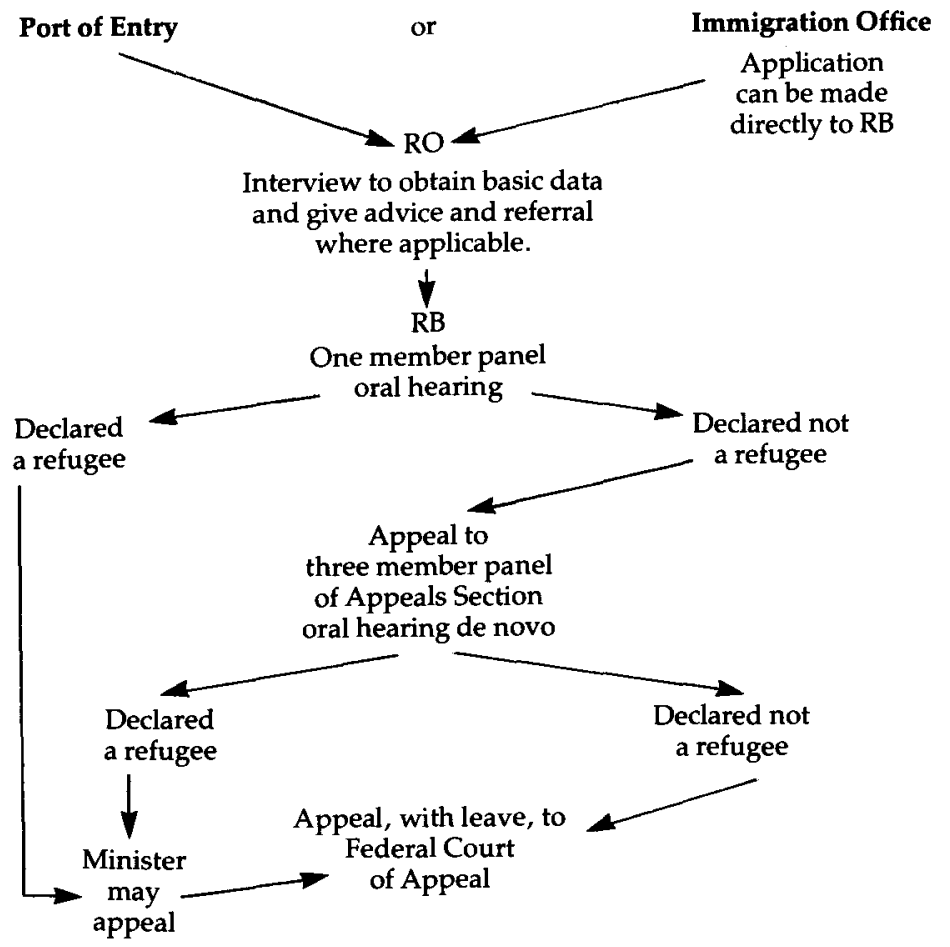

scheduling, publication of rules of procedure, the provision of written reasons for rejecting claims, the provision of adequate time for appeal and guarantees to ensure confidentiality especially in situations which pose dangers for the claimant and his/her family.

\section{Humanitarian Cases}

The Plaut Report notes that many refugee claimants are borderline cases. It recommends that both the ROs and the RB be allowed to refer cases on humanitarian and compassionate grounds to the Minister's Office. The RB may recommend favourable consideration. It is here that one can anticipate the new frontier of debate in the refugee area as delegates make pleas on behalf of fairer and institutionalized procedures governing special programs and consideration of individual cases which do not fall within the strict guidelines of the Convention Definition.

But the most contentious current debate is what to do about the 12,000 to 18,000 cases that are backlogged in the system. The Plaut Report recommended that CEIC process for landing the bulk of cases who come "from countries to which we do not return individuals, unless, of course, they represent a risk to our national security. Examples would be claimants from Afghanistan, Iran, El Salvador, Sri Lanka and most of the East Bloc countries." Similarly, special programs should be available to those individuals in the backlog who are "from areas of the world experiencing civil disorder, racial tension or violence." Finally, for those "who are presently involved in refugee determination . . . where there is a reasonable likelihood that the claimant may indeed be a refugee," Plaut recommends that "such doubt be resolved in favour of the claimant."

We would not need Bill C-55. The process would be relatively quick and inexpensive without giving into pleas for a universal, non-selective amnesty. We could also get on with the job of introducing the comprehensive legislation, based on the Plaut Report, that the Minister promised for this fall.

At the time of its release Flora MacDonald commended the report for its excellence. There is a 95 percent consensus on the recommendations by those involved in the refugee issue. The time for comprehensive legislative action is now. Howard Adelman is Director of the Refugee
Documentation Project at York University
and Editor of Refuge.

\section{Oral Hearings - A Right}

On April 30, 1985, the Supreme Court of Canada handed down a landmark decision requiring refugee claimants to be given an oral hearing. The following extract from the 72 page decision provides only the highlights.

\section{Background}

Appellants claim Convention refugee status as defined in s. 2(1) of the Immigration Act, 1976. The Minister of Employment and Immigration, acting on the advice of the Refugee Status Advisory Committee, determined pursuant to s. 45 of the Act that none of the appellants was a Convention refugee. The Immigration Appeal Board, acting under s. 71(1) of the Act, denied the subsequent applications for redetermination of status and the Federal Court of Appeal refused applications, made under s. 28 of the Federal Court Act, for judicial review of those decisions. The Court considered whether the procedures for the adjudication of refugee status claims set out in the Immigration Act, 1976 violate s.7 of the Canadian Charter of Rights and Freedoms and s. 2(e) of the Canadian Bill of Rights.

\section{Rationale}

Appellants, in the determination of their claims, are entitled to assert the protection of s. 7 of the Charter which guarantees "everyone the right to life, liberty and security of the person and the right not to be deprived thereof except in accordance with the principles of fundamental justice." The term "everyone" in s. 7 includes every person physically present in Canada and by virtue of such presence amenable to Canadian law. The phrase "security of the person" encompasses freedom from the threat of physical punishment or suffering as well as freedom from such punishment itself. A Convention refugee has the right under s. 55 of the Immigration Act, 1976 not to ". . . be removed from Canada to a country where his life or freedom would be threatened. ..." The denial of such a right amounts to a deprivation of "security of the person" within the meaning of s. 7. Although appellants are not entitled

Continued on $p .6$ 